\title{
Unfair Competition and Corporate Income Taxation*
}

\author{
Susan Rose-Ackerman $\dagger$
}

"If something is not done. .,, the macaroni monopoly will be in the hands of the universities.",

When a group of wealthy graduates donated the Mueller Macaroni Company to the New York University (N.Y.U.) Law School in 1948 , the university persuaded a court to give Mueller's profits taxexempt status because N.Y.U. was a nonprofit entity. ${ }^{2}$ Two years later, Congress amended the Internal Revenue Code to narrow this exemption: Henceforth, only the "related" business ventures of nonprofits would be tax exempt. ${ }^{3}$

Very little money has been collected under this provision. ${ }^{4}$ Instead, it has channeled the "active" investments of nonprofits into

* Research support for this paper was provided by Yale University's Program on NonProfit Organizations. I wish to thank Bruce Ackerman, Boris Bittker, George Cooper, Henry Hansmann, and John Simon for helpful comments.

$\dagger$ A.B. 1964, Wellesley College; Ph.D. 1970, Yale University. Professor of Law and Political Economy, Columbia University.

1. Revenue Revision of 1950: Hearings Before the House Commiltee on Ways and Means, 81st Cong., 2d Sess. 579-80 (1950) (remarks of Rep. Dingell), quoted in Note, The Macaroni Monopoly: The Developing Concept of Unrelated Business Income of Exempt Organizations, 81 HARv. L. REv. 1280, 1281 n.10 (1968) [hereinafter cited as Note, The Macaroni Monopoly].

2. See C.F. Mueller Co. v. Commissioner, 190 F.2d 120 (3rd Cir. 1951); Note, The Macaroni Monopoly, supra note 1, at 1281. N.Y.U. also owned a leather company, a piston ring factory, and a chinaware manufacturing operation. Other colleges and universities owned enterprises manufacturing automobile parts, cotton gins, and food products, and operated an airport, a street railway, a hydroelectric plant, and a radio station. See Kaplan, Intercollegiale Athletics and the Unrelated Business Income Tax, 80 ColuM. L. REv. 1430, 1432 (1980).

3. Revenue Act of 1950, Pub. L. No. 81-814, $\S \S 301,331,64$ Stat. 906, 947-53, 957-59 (codified at 26 U.S.C. $\S \S 502-514$ (1976)). Several commentators have reviewed this law. See Bittker \& Rahdert, The Exemption of Nonproful Organizations from Federal Income Taxation, 85 YALE L.J. 299 (1976); Cooper, Trends in the Taxation of Unrelated Business Activily, 29 INST. ON FED. TAX'N 1999 (1971); Kaplan, supra note 2; Note, Colleges, Charities and the Revenue Act of 1950, 60 YALE L.J. 851 (1951) [hereinafter cited as Note, Colleges, Charities, and the Revenue Act of 1950]. For a discussion of changes made in the treatment of nonprofit firms by the 1969 and 1976 tax law revisions, see Bittker \& Rahdert, supra, at 316-30; Kaplan, supra note 2, at 1431.

4. See Webster, Effect of Business Activities on Exempt Organizations, 43 TAXES 777 (1965). In the last six fiscal years the total tax collected was less than $.05 \%$ of corporate income tax collections. Total fiscal year collections were $\$ 24,970,000$ in $1977, \$ 27,470,000$ in 1978 , 
"related" areas. Universities, for example, are no longer in the pasta business, but they continue to sell housing and meals, perform contract research and testing, and operate publishing houses. ${ }^{5}$ Of course, the meaning of "related" is not obvious and the Internal Revenue Service (IRS) and the courts have experienced predictable difficulties settling on a definition. ${ }^{6}$ The unresolved issue of the law's coverage will be of growing concern to nonprofits since current cuts in marginal tax rates and in government subsidies will undoubtedly induce many nonprofit firms to consider profitmaking activities as a way to raise funds. ${ }^{7}$ As nonprofits try to enter new fields, such as genetic engineering and cooperative research relationships with private firms, ${ }^{8}$ Congress and the IRS will have to decide whether to facilitate or impede these activites, placing new strains on a genera-

$\$ 24,970,000$ in $1979, \$ 27,920,000$ in 1980 , and $\$ 34,310,000$ in 1981 . Internal Revenue Service, Data on Taxes Collected on Form 990T (unpublished IRS staff calculation).

5. Bromberg, University Audits by IRS, Philanthropy MONThly, Feb. 1980, at 18 (newsletter).

6. Some of this confusion arises because the law seeks to tax "unrelated" business activity, see I.R.C. § 513(a) (1976), even though the legislative history speaks of "unfair" competition. See Kaplan, supra note 2, at 1433-44. See also Treas. Reg. § 1.513-1(b), T.D. 7392, 1976-1 C.B. 162, 168-69. Mansfield, Some Aspects of Taxation of Business Income of Exempt Organizations, in 3 Staff of House Comm. on Ways \& MEANS, 86Th CoNG., 1st SesS., TaX Revision Compendium 2067 (House Comm. on Ways \& Means Comm. Print 1959) [hereinafter cited as TAX REvision COMPENDIUM]; Webster, supra note 4. For discussion and commentary on these exercises in definition, see Cooper, supra note 3; Grant, Taxation of Exempt Charitable Organizations Engaging in Business Activities, 4 U.C.L.A. L. REV. 352 (1957); Greenbaum, Business Dealings by Charities, 14 INST. ON FED. TAX'N. 127 (1956); Webster, supra note 4.

7. The cuts will reduce tax incentives for individuals to donate money by decreasing the value of the charitable deduction on the margin. This may well outweigh the "income effect" of the tax cut, i.e., taxpayers have more money to spend and may contribute some of this excess to charity. At the same time, government spending cuts will reduce nondonative sources of income for nonprofits and decrease publicly funded alternatives to private largesse. The Economic Recovery Tax Act of 1981 attempts to compensate for its disincentives to donate by means of an "above-the-line" charitable deduction for taxpayers who do not itemize their deductions. Economic Recovery Tax Act of 1981, § 121, I.R.C. § 170 (West Supp. 1982).

8. See, e.g. , N. BRODSKy, H. KaUfMaN \& J. TOOKER, UNIVERSITY/INDUSTRY COOPERATION (1980); Reinhold, Govemment Sonulinizes Link Between Genetics Industry and Universities, N.Y. Times, June 16, 1981, at 16, col. 1; Industry's Role in Academia, N.Y. Times, July 22, 1981, at D1, col. 3. But see note 66 infra.

At present, "all income derived from research for federal or state goverments and, in the case of a college, university or hospital, all income derived from research performed for any person" is tax-exempt under I.R.C. $\$ \$ 512(\mathrm{~b})(7)-(8)$. See Myers, Unrelated Business Income: $A$ Suddenly Explosioe Issue, in N.Y. Practicing Law Institute, Seventh Biennial Conference: Tax Planning for Foundations, Tax-Exempt Status and Gharitable ConTRIBUTIONS 223 (1978). 


\section{tion-old policy. ${ }^{9}$}

The particular problem of competition from nonprofits raises a more general issue. A variety of tax-favored entities compete with for-profit firms in a broad range of industries. ${ }^{10}$ When, if ever, will "unfair" competition by tax-favored firms be a legitimate problem for public policy? Congress's response to complaints of unfair competition has been inconsistent at best. The Internal Revenue Code has all but eliminated the tax advantage of mutual and cooperative banks and insurance companies, ${ }^{11}$ but agricultural cooperatives enjoy a relatively favorable tax status. ${ }^{12}$ Utilities operated by state and local governments are exempt from the corporate income tax, while private regulated companies are not. ${ }^{13}$

Instead of ad hoc responses to particular claims of unfair competition, we need a framework for analyzing the policy questions that arise whenever a tax-favored firm competes with firms that pay the corporate income tax. Two different claims, both based on the notion of "horizontal equity"14 are frequently confused in the policy debate. ${ }^{15}$ The first approach compares firms within the same industry

9. I address only one of the public policies that differentiate between firms on the basis of organizational form. For example, nonprofits obtain lower postal rates, exemption from property taxes, and favorable treatment on government contracts. See U.S. SMALL BUSINESS ADMinistration, GOVERnMENT Competition: A Threat to SMALl Business 74-79 (1980) (report of the advocacy task group on government competition with small business).

10. Recent data from the Census Bureau's 1977 Census of Service Industries indicate the extent to which taxable and tax-exempt firms coexist in various service industries. See U.S. Dep't of Commerce, Bureau of the Gensus, 1977 Census of Service IndusTRIES: Other Service INDustries 53-1-2, 53-1-3 (1981) (Geographic Area Series, No. SC77-A-53, pt. 1 (1981)) (Table 1, Summary Statistics for the United States: 1977) (surveying the major service industries where competition occurs, but omitting competition between subsidiary organizations, such as university book stores or cafeterias, and for-profit firms).

11. In the savings and loan and insurance industries, Congress has responded to complaints of "unfair" competition by equalizing the tax treatment of mutual and for-profit companies. See Klein, Income Taxation and Legal Entities, 20 U.C.L.A. L. REv. 13, 60 (1972).

12. The actual income tax laws facing cooperatives are complicated, but the basic implication of their special treatment is that they face lower tax rates on earnings than corporations. For a summary of the law, see M. ABrahamsen, CoOperattve Business ENTER PRISE 225-41 (1976). Cooperatives' lower tax liabilities arise mainly because the bulk of patronage dividends paid to members are not taxable to the cooperative. Agricultural cooperatives also have access to low-cost loans from special banks and from members' contributions. They are, however, unable to raise capital through public issues of common stock.

13. See Ely, Federal Taxation of Income of States and Political Subdivisions, in 3 TAx Revision COMPENDIUM, supra note 6, at 2091; Gilpin, Business Income of Exempt Organizations-Tax Equalization-Electric Utility Service Organizations, in 3 TAX REVISION COMPENDIUM, supra note 6, at 2077.

14. Horizontal equity is the principle that taxes should be equal for entities in equal positions. See A. Atkinson \& J. Stiglitz, Lectures on Public Economics 353-56 (1980).

15. A third claim should be kept separate because it deals with efficiency, not fairness. 
and asserts that it is unfair for the tax system to favor one competitor over another. ${ }^{16}$ The second approach compares for-profits across different industries-those with and those without tax-favored firms. Here it is said to be "unfair" for some firms to compete with taxfavored organizations when for-profit corporations in other industries compete only with taxable firms.

The first approach to horizontal equity makes the claim, for example, that N.Y.U. should pay taxes on its Mueller pasta business simply because the Ronzoni Company pays taxes on its macaroni profits. This view assumes that the fairness of tax policy should be assessed by comparing the income statements of the competing companies. But it is obvious that the ultimate impact of N.Y.U.'s pasta activities was not felt by the Ronzoni Company but by the human beings associated with it as investors, workers, and consumers. Sophisticated students of tax policy routinely incorporate this point in their assessments of fairness. Rather than speaking of fairness to corporate entities, they have pierced the organizational veil to consider the interests of human beings. ${ }^{17}$ Under this "person-oriented" perspective, the first fairness claim collapses. The different tax treatment of competing organizational forms does not imply that Ronzoni and N.Y.U. would charge different prices for their macaroni or pay different wages to their workers. It implies only that N.Y.U. would keep a larger share of Mueller's profits than would Ronzoni's owners. Once we look beyond the organization, this difference does not seem to violate principles of horizontal equity: Why must a fair tax code treat students and scholars who are the beneficiaries of Mueller's profits as if they were "equal to" Ronzoni's investors?

The second approach to horizontal equity gives a more meaningful interpretation to the complaints of Ronzoni's investors and will be used in the analysis that follows. Under this view, Ronzoni investors would argue that the relevant horizontal comparison is with investors in industries which do not face competition from tax-favored

Thus when for-profits are harmed as a result of the superior efficiency of tax-favored firms, the claim that the tax law gives the successful firms their competitive advantage is obviously unjustified. Rather than restrict this form of "unfair competition," the entry of efficient nonprofits ought to be encouraged. For an analysis of this claim, see Hansmann, The Rationale for Exempting Nonprofit Organizations from Corporate Income Taxation, 91 YALE L.J. 54 (1981). In such markets as daycare, hospitals, and education, for-profits may only be able to survive if they differentiate their product from that provided by nonprofits.

16. Klein, supra note 11, at 58 ("if the tax system favors one competitor over another without good reason, the unfavored competitor can properly claim injustice").

17. See, e.g. A. Atkinson \& J. Stiglitz, supra note 14, at 160-226; Warren, The Relation and Integration of Individual and Corporate Income Taxes, 94 HARv. L. REV. 717 (1981). 
firms. After all, at an earlier point in time, owners of shares in pastamaking companies could have chosen to invest in other businesses instead. In the absence of a tax on unrelated business activities, N.Y.U.'s entry into the pasta business would mean that investors who at one time were similarly situated are now earning different returns. This, at least, raises the possibility of a claim of horizontal inequity: If pasta investors are harmed, why should they be called on to bear a greater share than others of the social costs of tax favoritism to nonprofits? .

Legally trained commentators have avoided this normative question by doing some inadequate positive economics. They have argued that firms that compete with nonprofits are not generally worse off than those that compete only with for-profits. ${ }^{18}$ If this is true, the unfairness issue simply does not arise. I will demonstrate that previous analysts have dismissed the issue of "unfair" competition too quickly. While I agree that nonprofits are no more likely to engage in predatory pricing than for-profits, ${ }^{19} \mathrm{I}$ will show that for-profit investors may be injured even when predation does not occur. Forprofit investors' claims of injury are neither obviously correct nor patently false. Their validity depends both on one's definition of fairness and on a set of factual issues including the market structure of the industry in question, the information available to firms before they enter, the costs of leaving the industry, and the efficiency of capital markets. Both the firms that complain of injury and the legal scholars who minimize the problem of unfair competition have oversimplified the issue and missed critically important features of the problem.

The economic analysis in Part I proceeds in three stages. First, I discuss competition between taxable and tax-exempt firms in a competitive economy where entrants correctly foresee the presence of taxexempt competitors. Next, I drop the assumption of perfect foresight and show how for-profit firms will be affected by the tax and organi-

18. See Note, Preventing the Operation of Untaxed Business by Tax-Exempt Organizations, $32 \mathrm{U}$. CHI. L. Rev. 581, 591-92 (1965) [hereinafter cited as Note, Preventing Untaxed Business]. Sce also, Klein supra note 11, at 61-68; Note, The Macaroni Monopoly, supra note 1, at $1281 \mathrm{n} .11$; Note, Colleges, Charities and the Revenue Act of 1950, supra note 3, at 876.

19. Kaplan, supra note 2, at 1465-66; Klein, supra note 11, at 65-66; Note, Colleges, Charities and the Revenue Act of 1950 , supra note 3, at 876 . In an oligopolistic market prices may be lower if one of the competitors is nonprofit. See notes 45-54 infra and accompanying text. This price is not predatory in the usual sense of a seller who "cuts price below the level of its rivals' costs and perhaps also its own costs for protracted periods, until the rivals either close down operations altogether or sell out on favorable terms." F. SCHERER, INDUSTRIAL MARket Structure and Economic Performance 335 (2d ed. 1980). 
zational status of nonprofits in the case of unanticipated competition. To conclude Part I, I assume that the economy is imperfectly competitive, so that nonprofits compete with for-profits in an oligopolistic setting. After specifying in Part I the market conditions under which for-profit investors may be harmed, Part II turns to the normative question. I suggest that the distinctions made in the positive economic analysis will enlighten, if not fully resolve, the problems of identifying "unfair competition." The analysis demonstrates that the present tax on nonprofits' "unrelated" business income is exactly the wrong way to deal with the problem, generating more "unfairness" than it has prevented. While an economically sophisticated definition of unfairness is possible, its application involves subtle empirical issues-so subtle that they may be beyond the administrative capacities of the IRS. As a consequence, outright repeal of the tax on unrelated business activities seems like the best policy response.

\section{The Importance of Market Structure}

The policy debate has tended to view "unfair competition" in black-and-white terms. Either "unfairness" is the inevitable result of nonprofit entry, as for-profit firms and their congressional allies claim, or it almost never happens-as legal scholars assert. ${ }^{20}$ If, how-

20. For a summary of the arguments on both sides, see 1 TAX REVISION COMPENDIUM, supra note 6 , at 3 . The most extended discussion by a legal scholar is in Klein, supra note 11 . See also Bittker \& Rahdert, supra note 3; Kaplan, supra note 2; Note, The Macaroni Monopoly, supra note 1; Note, Colleges, Charities and the Revenue Act of 1950, supra note 3.

Spiro discusses several recent cases where for-profits claimed to suffer from "unfair" competition because of nonprofits' favorable tax status. See T. Spiro, "Unfair Competition" Between Taxable and Tax-Exempt Organizations: Three Case Studies (Supervised Analytic Writing, Yale University 1979). He looks at an unsuccessful travel industry challenge to the travel activities of the American Jewish.Congress and other tax-exempt organizations, Am. Soc'y of Travel Agents v. Blumenthal, 566 F.2d 145 (D.C. Cir. 1977), cert. denied, 435 U.S. 947 (1978). After losing in the courts, the travel industry attempted to influence IRS revenue rulings directly. A recent ruling was more favorable to the industry. See Rev. Rul. 78-43, 1978-1 C.B. 164 (stating that the University of North Carolina Alumni Association's travelincome was "unrelated," and hence taxable).

Spiro's second case involves the office products industry, where "sheltered workshops" for the handicapped compete with for-profit firms. The for-profits' trade association, the Office Products Manufacturing Association (OPMA), claimed unfair competition, but a Treasury Revenue Ruling upheld the tax exemption of sheltered workshops. See Treas. Reg. $\S 1.513-1$ (d)(4)(ii) (1967). Unlike the travel agents, OPMA has brought no court challenges and has concentrated on the important nontax advantages of sheltered workshops. See T. Spiro, supra.

A third example involves a court challenge brought by a taxable, commercial laboratory against a nonprofit corporation that promotes "manufactures, and the mechanic and useful arts." Structure Probe, Inc. v. Franklin Inst., 450 F. Supp. 1272 (E.D. Pa. 1978), affd, 595 F.2d 1214 (3d Cir. 1979). Structure Probe alleged that the Franklin Institute violated the 
ever, we try to locate the debate within a framework emphasizing market structure and imperfect information, the claims made on both sides seem overly broad.

For-profit firms advance two arguments to justify protection against nonprofit competition. First, they claim that nonprofits will cut prices below the prices that taxable firms could charge. Economically oriented legal commentators have generally dismissed the price cutting claim by arguing that if price cutting were profitable, forprofit competitors would do it too. ${ }^{21}$ But this argument ignores the possibility that nonprofits can affect market prices without resorting to overtly predatory behavior. Even in a competitive market where firms are too small to affect market prices individually, the entry of nonprofits could lower prices by shifting the overall industry supply curve. Nonprofits may be willing to enter an industry even when marginal for-profit firms are just breaking even. If for-profits cannot easily exit, supply will be larger, returns will be smaller, and price will be lower than in an industry without nonprofit firms. And in an oligopolistic industry, where individual firms can affect price levels, equilibrium prices might be lower when one of the major competitors is tax-exempt even though no one ever sets prices below cost. ${ }^{22}$

Second, for-profits argue that nonprofits will grow more quickly than for-profits and be less vulnerable to bankruptcy because they accumulate earnings faster. ${ }^{23}$ While these claims have been accepted by most legal scholars, ${ }^{24}$ their importance depends critically on the

Sherman Act, 15 U.S.C. $\$ 2$ (1976), in its sale of scanning electron microscope (SEM) services. The suit also claimed that the Institute's sale of SEM services violated its nonprofit charter. The court rejected both claims. $450 \mathrm{~F}$. Supp. at 1288, 1290.

21. See Kaplan, supra note 2, at 1466; Klein, supra note 11, at 65-66; Note, Colleges, Charities and the Revenue Act of 1950, supra note 3, at 876.

22. Price theory demonstrates that marginal firms will be earning a competitive rate of return on their investment. See note 28 infra and accompanying text. Readers unfamiliar with basic price theory should consult a basic microeconomics text such as J. HIRSHLEIFER, PRICE THEORY AND APPLICATIONS (2d ed. 1980).

23. See H.R. Rep. No. 2319, 81st Cong., 2d Sess. 579-80 (1950) ("The tax-free status of these . . organizations enables them to use their profits tax-free to expand operations, while their competitors can expand only with profits remaining after taxes."); Klein, supra note 11, at 255. There is a strong implication that firms do not have access to outside financing. See generally U.S. SMALL BUSINESS ADMINISTRATION, supta note 9.

24. See, e.g. Kaplan, supra note 2, at 1466 . One student commentator argues that a taxexempt business can accumulate a larger surplus than a taxable business, which may help it to weather lean years and to expand. See Note, Colleges, Charities and the Revenue Act of 1950 , supra note 3 , at 876 . Another argues that

the fast accumulation of capital made possible by tax-free profits is an advantage in any field. Where the market is expanding, the exempt enterprise will have a greater surplus to invest in production and distribution facilities, and, in anticipation of 
efficiency of capital markets. The more efficiently the capital market operates, the less important are retained earnings. If, however, lenders have difficulty evaluating a firm's investments, the firm may prefer to exploit internal sources of funds, and firms with high levels of retained earnings have an advantage. ${ }^{25}$

To assess the validity of the price cutting and retained earnings arguments, and thereby move from critique to contribution, requires a more systematic treatment that models the important market structures separately. To focus on the links among tax status, capital structure, and profitability, I will stylize the differences between firms in an extreme way. There are only two types of firms: for-profit corporations subject to the corporate income tax and nonprofit, taxexempt corporations that can issue no equity and must raise capital through borrowing or gifts. ${ }^{26}$ Nonprofit firms engage in tax-exempt business activity to provide funds to subsidize their primary activities. Therefore they want to maximize expected profits. I shall also assume that nonprofit firms are, on the average, as efficient as forprofits. Firms need not be identical, but any differences in costs or productivity are not systematically related to organizational form. The production of services by nonprofits is not complicated by ideological commitments or ineffective management. ${ }^{27}$ Only tax and cap-

higher net profits, can compete more effectively for supplies, capital assets, and outside financing. Even in an industry with inelastic demand the untaxed business will be able to invest in improvements at a faster rate than its competitors.

Note, The Macaroni Monopoly, supra note 1, at 1282. But see Klein, supra note 11, at 66-67 (denying the special importance of retained earnings); Note, Preventing Untaxed Business, supra note 18 , at 592 (same).

25. I assume here that profit-maximizing organizations will invest in the activities expected to yield the highest return. With perfect information and identical risk preferences, banks and firms would rank investment opportunities in the same way. Firms would be indifferent between borrowing from a bank or using their own funds, and borrowers could obtain funds either from banks or from firms lacking profitable investments within their own company. Asymmetric information changes this result. Banks and other lenders may have trouble monitoring a firm's use of investment funds. Therefore, they will charge an interest rate that takes account of this risk, and they may ration credit to the firm. In that case, retained earnings will be a cheaper source of funds for a firm than bank debt even taking into account "opportunity cost"-the return which the funds could earn if invested outside the firm.

26. Although I do not explicitly discuss the idiosyncracies of cooperatives, mutuals, or government corporations, much of the basic analysis can be applied to these organizations with a suitable modification of the assumptions concerning tax status and capital constraints.

27. I make this assumption not because it is necessarily realistic, but because it permits me to focus on the difference in tax treatment. Bittker and Rahdert suggest that "the business practices of charity-owned enterprises [may be] characterized more by caution than boldness." Bittker \& Rahdert, supra note 3, at 320. Their claim is, however, an empirical assertion that has not been supported by systematic investigation. See D. Young, If Not For-Profit, For 


\section{ital structure differences are important.}

\section{A. Anticipated Competition from Nonprofits}

If an industry were perfectly competitive with easy entry and exit of firms, complaints of "unfair competition" would always be invalid. A for-profit firm that was losing money in competition with a nonprofit would simply leave that industry and earn the competitive rate of return elsewhere. ${ }^{28}$

But in many situations, human and physical capital are not fungible, and exit is therefore costly. ${ }^{29}$ Even when exit is difficult, however, there is no reason to assume automatically that for-profit firms are suffering from "unfair" competition from nonprofits. In particular, whenever for-profits could reasonably have expected nonprofit competition at the time of their initial commitment to the industry, they would have included that fact in their calculations of expected returns and made their decision to invest accordingly. They would not 'have invested unless they expected to do at least as well there as in alternative investments. ${ }^{30}$ Therefore, in the case of anticipated

What? A Behaviorial Theory of the Non-Profit Sector Based on Entrepreneurship (1981) (unpublished manuscript, Yale University Program on Non-Profit Organizations) (case studies of nonprofit entrepreneurship).

28. In equilibrium in a competitive industry marginal firms earn zero "economic" profits and positive accounting profits. Their accounting profits include both a return to the equity capital invested in the firm, reflecting the opportunity cost of that capital, and the value of the entrepreneurs' time. Economic profits are only positive when a firm's return exceeds what owners could earn by withdrawing their money and time and investing them elsewhere in the competitive economy. On the distinction between economic and accounting profits, see J. HiRSHLEIFER, supra note 22, at 265. Bankruptcy costs would be small since they include only the administrative costs of going through the procedure. See Warner, Bankruplyy Costs, Absolute Prionity and the Pricing of Risky Debt Claims, 4 J. Fin. ECON. 239 (1977) (estimates of the relatively small administrative costs of railroad bankruptcies).

29. Capital is malleable before it is put in place, but once embodied in equipment it cannot be changed easily. A firm has many choices before it has embraced a particular investment strategy. After the plant and machinery are purchased, the firm's choices are limited by the resale market for specialized capital. See R. ALLEN, MACRO-ECONOMIC THEORY: A Mathematical Treatment 256 (1967).

30. If all such competition were anticipated by for-profit investors, then the ratio of taxable to tax-exempt capital in the economy as a whole might affect overall rates of return, but taxable firms in direct competition with tax-exempt firms would be at no special disadvantage.

Harberger argues that in a competitive economy, a tax on corporate profits will, in the long run, lower overall returns to capital irrespective of where the capital is invested. Harberger, The Incidence of the Corporation Income Tax, 70 J. POL. ECON. 215 (1962). See McLure, General Equilibrium Incidence Analysis: The Harberger model afler ten years, 4 J. PuB. ECON. 125 (1975), for an assessment of Harberger's contribution and a summary and critique of the research spawned by Harberger's original article.

In contrast to Harberger, Stiglitz contends that in the absence of bankruptcy risks the 
competition, no claims of unfairness can be substantiated even if exit is difficult. This argument is independent of any particular model of nonprofit behavior. So long as the entry and subsequent behavior of nonprofits were anticipated, taxable firms could have no grounds for complaint.

The real world, however, frequently does not conform to the stringent conditions imposed here. The next section examines the fairness claims that might arise if exit is costly and if competition from nonprofits is unanticipated.

\section{B. Unanticipated Competition}

Competitive returns represent the opportunity cost of money and time invested in the firm. If entrepreneurs and investors had chosen not to establish a particular firm, they could have invested elsewhere at competitive rates. If a firm earns less than this competitive return and if exit is costly, the owners will suffer losses relative to what they could have earned elsewhere. Thus, one can pose the issue of unanticipated competition in the following way: Suppose that investors, when they decide to enter an industry, anticipate that all competitors will be for-profit firms. When many of the competitors turn out to be nonprofits, under what conditions should we expect the investors to earn "subcompetitive" returns?

In the absence of conscious predatory behavior, the only way nonprofits can affect for-profits is through "excessive" entry. That is, because of the tax treatment of nonprofits and the costs of exit, the industry has more firms, earning lower gross returns, than the forprofit investors expected ex ante. To show how "excessive" entry can occur, suppose that nonprofit entrepreneurial activity is concentrated in a single industry and that the nonprofit sector is small relative to

corporate profits tax can be viewed as a lump-sum tax on corporations so long as the personal tax rate on bond interest exceeds the corporate rate. See Stiglitz, Taxation, Corporation Financial Policy and the Cost of Capital, 2 J. PuB. ECON 1 (1973). This result depends on features of the tax law Harberger does not consider-that is, "on the interest deductibility provisions and on the fact that capital gains are taxed only upon realization." Id. at 33. If interest payments are not deductible, and if depreciation allowances equal true depreciation, then the tax is distortionary and capital flows from the taxed to the untaxed sector. King notes that "[t]his is similar to the conclusions of Harberger's (1962) model except that in our case equilibrium is determined by marginal and not average rates of return." King, Taxation, Corporate Financial Poligy, and the Cost of Capital: A Comment, 4 J. PUB. ECON. 271, 276 (1975). Stiglitz pulls together and extends the discussion by viewing the tax in turn as "a tax on capital in the corporate sector, a tax on entrepreneurship in the corporate sector, a tax on pure profits in the corporate sector, and a tax on risk taking." Stiglitz, The Corporation Tax, 5 J. PUB. ECON. 303, 303 (1976). 
the economy as a whole. Therefore, the sector's investment decisions have no noticeable effect on overall market rates of return. I shall also make the realistic assumption that, despite the tax avoidance potential of $100 \%$ debt financing, profit-maximizing taxable firms will have capital structures that mix debt and equity. ${ }^{31}$

Given these assumptions, we can derive the formal conditions under which nonprofit entry can depress for-profit returns below competitive levels. ${ }^{32}$ Basically, "excessive" entry occurs when non-

31. Taxable firms can deduct interest paid on debt, but all returns to equity are taxed. Given this fact, for-profit firms might avoid taxes on profits by relying entirely on bonds to raise capital. If firms were $100 \%$ debt financed, the corporate income tax would be a tax on the pure or "economic" profits of inframarginal firms. See note 28 supra. The tax would not affect any firm's marginal choices, and hence firms would not care about the tax status of their competitors. In a competitive world, the marginal firms earn no excess "economic" profits, and hence the tax treatment of profits would be irrelevant. For-profit firms would be indifferent to the tax status of their competitors, and no issue of "unfair" competition would arise.

Despite these tax incentives, for-profits do not rely solely on debt for their capital requirements. There appear to be several reasons for this, one of which is the IRS's disfavor for $100 \%$ debt financing. See B. BitTkER \& L. StONe, FEderal InCOME TAXation 783-785 (5th ed. 1980). In addition, the more highly leveraged a firm is, the more likely are lenders to require higher rates on loans. These higher rates reflect the practical difficulties of monitoring managers and the increased likelihood of bankruptcy as the ratio of loans to equity increases. Therefore, a for-profit firm faces a cost of capital that depends on its capital structure and may well prefer a mixture of debt and equity in spite of the tax advantages of debt.

Modigliani and Miller initiated the current literature on firm capital structure. See Modigliani \& Miller, The Cost of Capital, Corporation Finance and the Theory of Investment, 48 AM. ECON. REV. 261 (1958) (arguing that in a competitive world, with perfect capital markets, no taxes and no risk of bankruptcy, the capital structure of a firm has no effect on its value). Their article was followed by numerous attempts to develop alternative models, including models stressing monitoring and agency costs. See e.g., Stiglitz, Some aspects of the pure theory of corporate finance: bankrupticies and take-overs, 3 BELL J. ECON. \& MGMT. ScI. 458 (1972); Jensen \& Meckling, Theory of the Firm, Managerial Behavior, Agency Costs and Ownership Structure, 3 J. FIN. ECON. 305 (1976); Myers, Determinants of Corporate Borrowing, 5 J. FIN. ECON. 147 (1977); Ross, The Determination of Financial Structure: The Incentive-Signalling Approach, 8 BELL J. ECON. 23 (1977).

Miller, however, argues both that bankruptcy costs and agency costs are small and that the tax advantages of debt have been overrated. Miller, Debt and Taxes, $32 \mathrm{~J}$. FiN. 261, 263-64 (1977). He further argues that equity investments are beneficial to high bracket taxpayers since capital gains are taxed at a lower rate than bond interest payments, and that this fact will be reflected in the market returns to bonds and stocks. Id. at 266-68. Thus, the tax laws will determine the debt-equity ratio for the economy as a whole, but there is no optimum ratio for any individual firm. Id. at 269. This result, of course, depends upon the assumption of insignificant bankruptcy and agency costs so that lenders are indifferent to the debt-equity ratios of individual firms.

32. Suppose that individual investors all have the same preferences toward risk, and that capital markets are competitive with market rates set so that individual investors are indifferent between bonds and stocks. To characterize this fact, suppose that there is a riskless asset which earns an after-tax rate of return of $v$ and that all risky assets have nominal or expected returns set so that they are equivalent to a certainty of $v$. To avoid unnecessary 
profits have excess cash to invest and the return they can obtain by lending their money on the bond market is lower than the rate of return on active, entrepreneurial investments. ${ }^{33}$ This will often be the case under my assumptions if the corporate tax rate exceeds the tax rate on individual income and if capital gains taxes are low. Nonprofits will continue to enter until their presence drives down industry returns to the point where marginal nonprofits are indifferent between passive and active investments. When that happens, marginal for-profits will want to leave the industry because they will be earning "subcompetitive" returns that are less than the market return on riskless assets. Because of the costs of exit, those firms will earn less than market returns whether they stay in business, go bankrupt, or sell out. ${ }^{34}$

complications, assume that firms issue no dividends, that the personal income tax rate on bond interest is $s$, that capital gains are untaxed, and that the corporate tax rate is $\ell$. This means that the nominal rate on bonds is $r$ where $r=v /(1-s)$ and that the gross profit rate is $w$ where $w=v /(1-t)$.

Suppose, further, that a nonprofit has some excess cash to invest. Since its interest earnings are tax-exempt, the nonprofit can earn the equivalent of $r$ if it invests in the bonds of other firms. If it operates a tax-exempt business itself, it will earn $w$ so long as the nonprofit believes that it will be just as efficient as the marginal for-profit.

Thus, in this simple case, it will establish a new business if $w$ is greater than $r$, that is, if $t$ exceeds $s$. When this condition holds, the nonprofit obtains tax benefits from either type of investment, but the benefits are greater for productive or "active" investments. If there are many nonprofits in this same situation, they will enter the industry until the marginal nonprofit earns $r$ from its productive investment. At that point, many for-profit firms may want to leave the industry. Any firm that earned a pretax return of $w$ before the entry of nonprofits is now earning $r$, which is less than $w$ when $t$ is greater than $s$.

33. If nonprofits were taxed on all productive "business" activities but not on passive investments, then in equilibrium nonprofits would compare the rate of return on active investments with the rate for a hypothetical risk-free investment. If we assume that they can earn no more than the marginal for-profit in an active investment, then nonprofits would only invest in bonds since they would still be tax-exempt. (I assume throughout that nonprofits are such a small force in the bond market that the rate of return is unaffected by their choice.)

Students of public finance may wonder how this rather large change in behavior can be consistent with Stiglitz's claim that, under certain conditions, the corporate income tax does not affect investment choices. See A. ATKINSON \& J. STIGLITZ, supra note 14, at 142-46; Stiglitz, supra note 30 , at 32 . Stiglitz considers a case with no bankruptcy risks, where marginal investments are financed by borrowing, interest payments are deductible, and true economic depreciation is deducted to compute tax liability. Then, the firm's marginal investment decisions will remain unchanged whether or not it is subject to the corporate income tax. Furthermore, if the depreciation allowance exceeds economic depreciation, the tax system may actually encourage investment. This result, however, refers only to the marginal behavior of existing firms. Stiglitz assumes competitive markets and does not deal explicitly with entry and exit. Thus, while the marginal choices of nonprofits may well be unaffected, they will seek to make a discontinuous change and exit from the industry if their profits become taxable.

34. In the case discussed in text, the nonprofits' impact on for-profits turns on the asym- 
The importance of this conclusion depends, first, on the concentration of nonprofit investments in particular industries; second, on the number of marginal for-profit firms in any industry earning only competitive returns; and third, on the assumption that nonprofits have excess cash available for investment. If the productive activities of nonprofits are broadly diffused, there will be little impact on profits anywhere in the economy. In fact, if tax-exempt firms have no special efficiency advantages in any industry, one would expect them to seek to maximize returns by establishing firms in a broad range of industries, thus earning close to a competitive return in each one. Since nonprofits control only a small proportion of the economy's resources, ${ }^{35}$ one would not expect them to be able to push returns down much below ordinary competitive rates if their funds were evenly spread across the economy. Further, if most for-profit firms are more than marginally profitable, few firms will want to exit from industries which nonprofits enter, although all will earn somewhat less than they did before the entry of nonprofits.

Finally, if the nonprofits must borrow funds from banks or other lenders, the cost of capital may be too high to make active entrepreneurship worthwhile, even if the corporate tax rate exceeds the individual rate. Nonprofits might, for example, be charged rates that exceed competitive returns because lenders have difficulty monitoring the nonprofits' behavior. ${ }^{36}$ Nonprofit managers must then decide whether to use a combination of gifts and loans to start new businesses, taking into account that nonprofits cannot enjoy the tax advantages of debt that accrue to for-profits. The smaller the pool of internal funds available to the nonprofit, the higher the rate of interest charged, and the larger the efficient scale in the industry, the less likely it is that active nonprofit entry will occur. Indeed, if the cost of borrowing is high enough, entry may only occur if the nonprofit is

metric tax treatment of bonds and stocks, not on the nonprofits' tax advantages per se. Suppose, for example, that nonprofits faced the same tax rate on both bonds and stock. Then they would also favor direct investment over bond purchase so long as $t$ is greater than $s$ for other investors. See note 32, supra.

35. See Hansmann, The Role of Nonproft Enterprise, 89 YALE L.J. 835, 835 n.1 (1980) (estimating that the nonprofit sector accounted for about $2.8 \%$ of national income in 1974).

36. This could happen if lepders believe that nonprofit organizations are particularly untrustworthy users of investment funds. Lenders might prefer to lend to entrepreneurs with some direct ownership interest in the enterprise who will benefit financially if returns are high. See Jenson \& Meckling, supra note 31. Compare this supposition about the relative untrustworthiness of nonprofits as borrowers with the argument that nonprofits may be seen as more trustworthy than for-profits by donors and consumers. See Hansmann, supra note 35. 
more efficient than existing marginal for-profits. ${ }^{37}$ But in that case, if some for-profits were eventually driven out of business, there would be a net efficiency gain. ${ }^{38}$

Of course, there is no reason to believe that a nonprofit's capital structure disadvantages just match its tax advantages. Efficient forprofits may suffer losses if the entry of nonprofits is concentrated in their industry, or efficient nonprofits may fail to enter because they are unable to obtain adequate and affordable capital. If, as I have assumed, efficiency is not systematically associated with organizational form, then the form that is most favored by the tax system and the capital market in a particular situation would be able to exploit whatever opportunities arise. It is therefore possible that some efficient for-profit entrepreneurs and investors will earn subnormal returns if nonprofit entry is concentrated in a few industries. The extent of loss cannot categorically be affirmed or denied; it is an empirical issue to be resolved on a case-by-case basis.

\section{Oligopoly}

The impact of tax-exempt firms on their taxable competitors can be quite different if an industry is oligopolistic rather than competitive. ${ }^{39}$ I shall show that the claims of for-profit firms to suffer "harm" may well be valid in an oligopoly with a fixed number of firms.

\section{Effect of nonprofit status on output.}

In an oligopolistic market, a firm's tax status may affect its marginal choices, and a tax-exempt firm may have a higher output and a larger effect on market price than a tax-paying firm. ${ }^{40}$ To see how this can happen, consider a simple duopoly model in which a for-

37. Tax disadvantaged firms, see note 34 supra, would be unable to borrow at all unless they were markedly more efficient than ordinary for-profit firms.

38. If as Hansmann, supra note 15, supposes, nonprofit firms are inefficiently capital constrained because of their inability to raise equity capital, then the likelihood that their forprofit competitors will earn subnormal returns is low so long as the two organizational forms are equally efficient.

39. The authors in Note, Preventing Untaxed Business, supra note 18, never go beyond competitive assumptions. Klein, supra note 11 , at $61-66$, uses an oligopoly model in which firms do not behave strategically. An oligopoly model is also implicit in Note, Colleges, Charities, and the Revenue Act of 1950, supra note 3, at 876, while competitive assumptions are implicit in Note, The Macaroni Monopoly, supra note 1, at 1281 .

40. These issues did not arise in Part I-B because the firms were in a competitive industry. No individual firm could affect the performance of the industry by its choice of output level or price. In an oligopolistic industry this is no longer true. The essence of an oligopolistic industry is the close link between the behavior of one firm and the performance of another. 
profit firm $A$, faces a single competitor $B$, which may be either a taxexempt nonprofit financed by gifts and debt or a taxable for-profit. Assume, first, that there is no risk of bankruptcy and that lenders require the same minimum rate of return on both bonds and stocks. ${ }^{41}$ Lenders require for-profit firms to maintain a ratio of debt to total capital below a specified level, and all firms purchase debt at a fixed rate that is independent of the debt-equity ratio and the level of private giving to nonprofits. ${ }^{42}$

Whatever its tax status, firm $B$ produces the quantity that maximizes profits by equating the marginal revenue gain from an increase in output (after tax for the for-profit firm) with the sum of the marginal increases in operating costs and capital costs from the same increase in output (again, after tax for the for-profit firm). Firm $B$ 's profit-maximizing output will depend on its tax status if the tax affects its marginal decisions. This is true under the current system which taxes "accounting" rather than "economic" profits. That is, the tax is levied only on the return to equity, not on capital costs that take the form of interest on debt. ${ }^{43}$ So long as some of its marginal capital cost is raised through stock issues, then, it costs the for-profit more to expand production than it does a comparable nonprofit. At the level of output that maximizes net profits for the for-profit, marginal revenues would exceed marginal costs for the nonprofit. Therefore, as long as marginal revenue falls with increases in output and marginal operating and capital costs increase or remain constant, the nonprofit will choose a higher level of output than the similarly situated for-profit. ${ }^{44}$

41. I thus abstract from differences in the tax treatment of these individual investments as well as from the relative riskiness of different types of investments.

42. I later consider the risks of bankruptcy and default. See text accompanying notes 48-53 infra.

43. To an economist, one of the costs of doing business is to provide a "normal" rate of return to invested capital, equal to what could be earned in alternative investments. "Economic" profits are measured as the excess of revenues over these and other costs. See note 28 supra.

44. If the corporate tax were levied on "economic" profits, firm $B$ 's tax status and capital structure would be irrelevant, and firm $A$ would be indifferent to the tax status of its competitor. It may look with envy at the higher profits of the tax-exempt firm, but these profits have no effect on its own performance.

To see this, suppose that firm $B$ acts like a Cournot oligopolist. In other words, $B$ maximizes profits holding the quantity $A$ produces constant. See J. Henderson \& R. QUandT, Microeconomic Theory: A Mathematical APProACH 222-31 (1971).

Let $B$ 's profits, $\Pi_{B}$, be

$$
\Pi_{B}=\left[\mathrm{p}(\mathrm{q}) \mathrm{q}_{B}-\mathrm{c}\left(\mathrm{q}_{B}\right)\right](1-\mathrm{t})
$$




\section{Impact on for-profit competitors.}

We are now ready to ask how the for-profit firm, $A$, is affected by the organizational and tax status of its competitor, $B$. Suppose, for

$$
\text { where } \begin{aligned}
\mathrm{p} & =\text { price, } \\
\mathrm{q}_{A} & =\text { quantity produced by } A, \\
\mathrm{q}_{B} & =\text { quantity produced by } B, \\
\mathrm{q} & =\mathrm{q}_{A}+\mathrm{q}_{B}, \\
\mathrm{c}\left(\mathrm{q}_{B}\right) & =\text { total cost of producing } \mathrm{q}_{B}, \\
\mathrm{t} & =\text { corporate tax rate. }
\end{aligned}
$$

Then, if the second order conditions hold, $B$ 's profits are maximized at:

$$
\frac{\mathrm{d} \Pi}{\mathrm{dq}_{B}}=(1-\mathrm{t})\left[\mathrm{p}^{\prime}(\mathrm{q}) \mathrm{q}_{B}+\mathrm{p}-\mathrm{c}^{\prime}\left(\mathrm{q}_{B}\right)\right]=0
$$

In a Cournot model, $\mathrm{p}^{\prime}(\mathrm{q})=\frac{\mathrm{dp}}{\mathrm{dq}}$ since firm $B$ takes $A^{\prime}$ 's output as given. Clearly, the level of $\mathrm{q}_{B}$ that solves (2) does not depend upon $B$ 's tax rate. Firm $A$ does not care about the tax status of its competitor. See Klein, supra note 11, at 63 (presenting a simple preliminary model); Note, Preventing Untaxed Business, supra note 18, at 591-92.

In contrast, when the tax is levied on "accounting" profits, a firm's tax status can affect its behavior. Then in long-run steady state equilibrium, "economic" profits are:

where $\hat{\mathrm{c}}\left(\mathrm{q}_{B}\right)=$ operating costs,

$$
\Pi_{B}=(1-\mathrm{t})\left[\mathrm{p}(\mathrm{q}) \mathrm{q}_{B}-\hat{\mathrm{c}}\left(\mathrm{q}_{B}\right)-\mathrm{rB}\left(\mathrm{q}_{B}\right)\right]-\mathrm{rE}\left(\mathrm{q}_{B}\right) \text {, }
$$

$r \quad=$ interest rate,

$\mathrm{B}\left(\mathrm{q}_{B}\right)=$ dollar value of capital raised by sales of bonds,

$E\left(q_{B}\right)=$ dollar value of other capital from equity or gifts.

Let $K\left(q_{B}\right)=$ dollar value of capital, let $\beta$ equal the ratio of debt to total capital required by those who lend to for-profits, and let gifts equal some fixed dollar amount, $\bar{G}$. (I do not analyze the general strategic question of the trade-off between debt financing and the generation of private donations.) We can now ask how a competitor will act if, on the one hand, it is a for-profit with $\mathrm{t}>0, \beta<1, \mathrm{~B}\left(\mathrm{q}_{B}\right)=\beta \mathrm{K}\left(\mathrm{q}_{B}\right)$ and $\mathrm{E}\left(\mathrm{q}_{B}\right)=(1-\beta) \mathrm{K}\left(\mathrm{q}_{B}\right)$, or, on the other hand, a nonprofit with $\mathrm{B}\left(\mathrm{q}_{B}\right)=\mathrm{K}\left(\mathrm{q}_{B}\right)-\overline{\mathrm{G}}$, and $\mathrm{E}\left(\mathrm{q}_{B}\right)=\overline{\mathrm{G}}$. Capital raised through gifts has the same opportunity cost as equity capital since it can be invested at rate $r$. Thus, for the taxable for-profit firm:

$$
\Pi_{B}^{1}=(1-\mathrm{t})\left[\mathrm{p}(\mathrm{q}) \mathrm{q}_{B}-\hat{\mathrm{c}}\left(\mathrm{q}_{B}\right)-\mathrm{r} \beta \mathrm{K}\left(\mathrm{q}_{B}\right)\right]-\mathrm{r}(1-\beta) \mathrm{K}\left(\mathrm{q}_{B}\right) .
$$

For the nonprofit:

$$
\Pi_{B}^{2}=\mathrm{p}(\mathrm{q}) \mathrm{q}_{B}-\hat{\mathrm{c}}\left(\mathrm{q}_{B}\right)-\mathrm{rK}\left(\mathrm{q}_{B}\right) .
$$

Maximizing $\Pi_{B}^{1}$ and $\Pi_{B}^{2}$ with respect to $\mathrm{q}_{B}$, and assuming the second order conditions hold, yields for the for-profit;

$$
0=(1-t)\left[p^{\prime}(q) q_{B}+p-\hat{c}^{\prime}\left(q_{B}\right)-\beta r K^{\prime}\left(q_{B}\right)\right]-r(1-\beta) K^{\prime}\left(q_{B}\right),
$$

and for the nonprofit;

$$
0=\mathrm{p}^{\prime}(\mathrm{q}) \mathrm{q}_{B}+\mathrm{p}-\hat{\mathrm{c}}^{\prime}\left(\mathrm{q}_{B}\right)-\mathrm{rK}^{\prime}\left(\mathrm{q}_{B}\right) .
$$

In the short run, if capital is fixed so $K^{\prime}\left(q_{B}\right)=0$, both types of competitors make the same profit maximizing output choices. If, instead, capital can be varied, the nonprofit will produce more output. To see this, suppose that each firm produces the same output. But then $-t\left(\mathrm{p}^{\prime} \mathrm{q}_{B}+\mathrm{p}-\hat{\mathrm{c}}^{\prime}\left(\mathrm{q}_{B}\right)-\beta \mathrm{rK}^{\prime}\left(\mathrm{q}_{B}\right)\right)$ would have to equal zero. Substituting from (7), this implies that $-\mathrm{t}(1-\beta) r \mathrm{~K}^{\prime}\left(\mathrm{q}_{B}\right)=0$. But this is impossible so long as the marginal product of capital is positive. Thus, in general, when (7) is solved for $\mathrm{q}_{B}$ so that the nonprofit is maximizing net returns, the for-profit has marginal after-tax costs that exceed marginal revenues. So long as marginal costs increase (or remain constant) with $q$, and marginal revenues fall, 
concreteness, that both firms behave as Cournot oligopolists. ${ }^{45}$ That is, each one maximizes profits assuming that the output of its rival remains constant. We can then draw reaction functions ${ }^{46} \psi_{A}$ and $\psi_{B}$ that show how firms $A$ and $B$, respectively, will respond to the output choices of the other firm. Thus $\psi_{A}$ shows the profit-maximizing output chosen by $A$, given its belief about $B$ 's output choice.

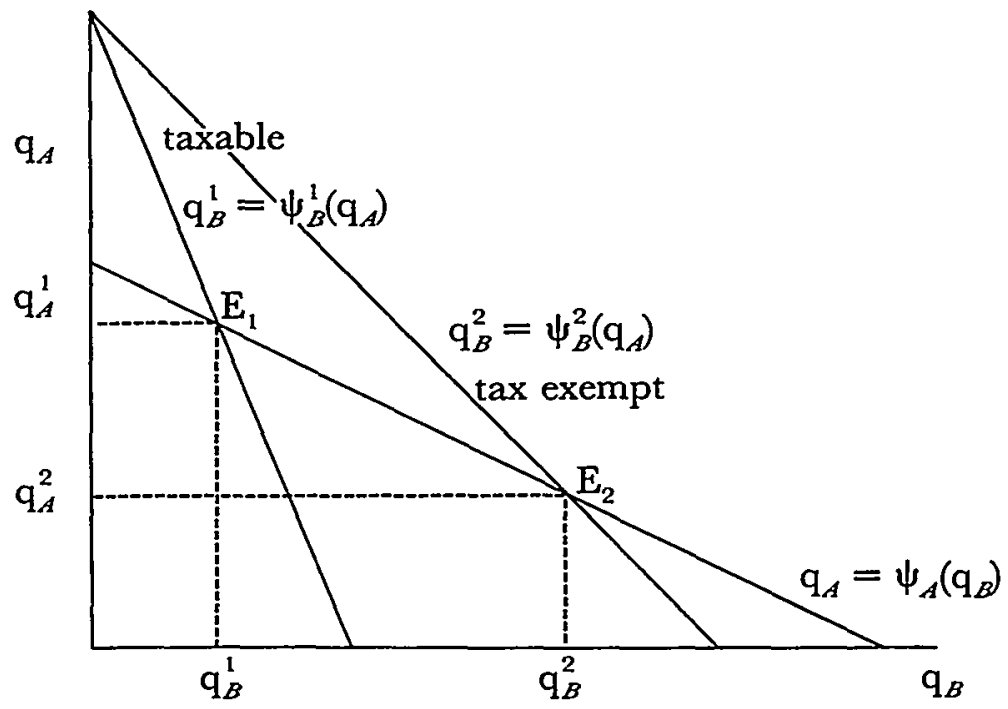

FIGURE 1

Figure 1 illustrates a possible set of reaction functions where $\mathrm{q}_{A}$ is $A$ 's output and $\mathrm{q}_{B}$ is $B$ 's output. They have been drawn as straight lines, but all we really know is that they are downward sloping. ${ }^{47} \mathrm{We}$ established above that, ceteris paribus, $B$ produces more when it is taxexempt than when it is taxable. Thus, the reaction function of the tax-exempt firm, $\mathrm{q}_{B}^{1}$, is everywhere above that of the taxable firm, $\mathrm{q}_{B}^{2}$, except when $\mathrm{q}_{B}=0$. Since, under the Cournot model, the reaction function for $A$ is unaffected by $B$ 's tax and organizational status, the equilibrium level of $\mathrm{q}_{B}$ is higher and that of $\mathrm{q}_{A}$ is lower when $B$ is

the level of output chosen by the nonprofit is too large for the for-profit. Therefore, firm $A$ is better off if its competitor is a for-profit firm.

The basic idea of this modeling exercise is that nonprofits set marginal revenue (MR) equal to marginal variable cost (MVC) plus marginal capital cost (MKC), while for-profits set $(1-t) M R$ equal to $(1-t) M V C+(1-\beta t) M K C$. Since $\beta<1,(1-t)$ is smaller than $(1-\beta t)$. Thus MR-MVC is larger than MKC at the taxable firm's profit-maximizing output.

45. See J. HENDERSON \& R. QUANDT, supra note 44, at 222-28.

46. See id. at 226 (explaining reaction functions).

47. The lines slope downward because firm $A$ maximizes profits at a lower level of output the higher the output of firm $B$, and vice versa. See id. at 222-28. 
tax-exempt. $A$ is unambiguously worse off when its competitor is a tax-exempt nonprofit.

\section{Importance of bankruptcy risk.}

But this simple model overstates the injury that a nonprofit can impose on a for-profit. To proceed further, we should take account of the possibility of bankruptcy and default. In general, the interest rate lenders can charge is not fixed for all borrowers. Lenders charge highly leveraged firms higher rates to compensate for their increased risks of bankruptcy. ${ }^{48}$ Unless nonprofits are very well endowed or have superior access to donations, they must finance themselves with debt. The risk of bankruptcy may therefore be lower for for-profits since they are partially financed by equity investments. This may make for-profit firms more effective competitors because they have superior access to capital funds. The advantages of the for-profit's capital structure and the risk-sharing feature of the corporate income $\operatorname{tax}^{49}$ may outweigh the for-profit's tax disadvantages. As a consequence, the nonprofit may produce less output than a for-profit because the nonprofit is either rationed in the capital market, ${ }^{50}$ or charged high rates by lenders. $A$ may now prefer to face a nonprofit competitor. ${ }^{51}$

When bankruptcy is possible, firm managers and shareholders will be concerned not only with expected return but also with risk. In a duopoly or oligopoly, management would therefore be concerned both with its own absolute level of resources and with its vulnerability to bankruptcy relative to other firms in the industry: Ceteris paribus, a firm's risk of bankruptcy is negatively related to its competitors' risks. To see this, one need only recognize that if demand is unexpectedly low, everyone faces a heightened risk of bankruptcy, but a firm's risk is lower if there are other firms that are more margi-

48. The risk is higher because more of the firm's debt takes the form of fixed rate securities that must be repaid so long as any excess over operating costs is available. With equity investment, a firm's owners and managers have more freedom to decide how much income to pay out in dividends and how much to retain for investment and as a hedge against losses.

49. See Gordon, Taxation of Corporate Capital Income: Tax Revenue v. Tax Distortions (1981) (unpublished manuscript, Bell Laboratories) (stressing the risk-spreading benefits of the corporate income tax); Stiglitz, The Corporation Tax, 5 J. PUB. ECON. 303, 307-08 (1976) (same).

50. See D. Jaffee, Credit Rationing and the Commercial Loan Market (1971) (attempting to explain why lenders may ration credit rather than raising interest rates); Jaffee \& Russell, Imperfect Information, Uncertainty, and Credit Rationing, 90 Q. J. EcON. 651 (1976) (same).

51. In Figure 1, the positions of $\mathrm{q}_{B}^{1}$ and $\mathrm{q}_{B}^{2}$ would be reversed. 
nal than it is. Marginal firms, with the smallest cushion of past profits, will exit first, thus pushing up prices and improving market conditions for those that remain.

In this regard, for-profits frequently claim that nonprofits are less likely to go bankrupt than for-profits. Since exit normally implies a loss of wealth and outside sources of capital are not always available to tide a firm over bad years, retained earnings can be an important factor in a firm's survival. Because of their exemption from the corporate income tax, nonprofits are believed to accumulate more earnings in good years to cover losses in subsequent years. If this claim is correct, the relative immunity of nonprofits makes their for-profit competitors relatively more vulnerable to bankruptcy. The truth of this claim, however, depends on the availability of loss carryovers in the tax law. If there is full carryover, a firm is never taxed unless it actually earns profits over time. Thus, whether the nonprofit firm has an advantage in the bankruptcy context turns on the existence and completeness of loss carryovers, not on the corporate tax exemption alone. In fact, although loss carryover provisions are not complete, they are quite generous-losses generally can be carried back three years and forward fifteen years. ${ }^{52}$ When profits oscillate from positive to negative as time passes, a taxable firm is treated almost like a tax-exempt firm on any gains which are balanced by losses in other years. For-profits will only be disadvantaged when they have a run of losses that lasts more than eighteen years with major losses in the middle of the period-more than three years after the last profit in the past and more than fifteen years before the first profit in future. ${ }^{53}$ In short, nonprofits' lower risk of bankruptcy has been overemphasized by their for-profit competitors. Current tax law treats the two organizational forms almost identically.

In conclusion, a for-profit oligopolist would prefer to compete with another for-profit whenever nonprofits have no special difficulties obtaining capital and corporate loss carryover provisions are in-

52. I.R.C. $§ 172(\mathrm{~b})$ (West Supp. 1982).

53. In an inflationary world, loss carryforwards are less valuable than loss carrybacks unless they are somehow indexed to take account of price changes.

In addition to the loss carryover provisions, the Economic Recovery Tax Act of 1981 provides another benefit to loss-making corporations. The "safe harbor lease" provision of the Act allows them to sell their unused investment tax credits by engaging in sale-leaseback arrangements with business organizations in high marginal tax brackets. See Economic Recovery Tax Act of $1981, \S 201$ (a), I.R.C. $\$ 168(f)(8)$ (West Supp. 1982). Tax-exempt nonprofits are not eligible to participate since the law requires that both sides of the transaction be eligible to receive the investment tax credit. The only exception is for mass transportation vehicles, $i d$, a clause designed to benefit cities with large mass transit systems. 
complete. But the for-profit will prefer a nonprofit competitor whenever nonprofits have difficulty raising capital, and are therefore small and ineffective competitors. ${ }^{54}$ Once again, while "harm" is possible, its extent depends upon a set of factual conditions determined by the details of the tax law and the operation of the capital market.

\section{II. "UNFAIR COMPETITION" AND ECONOMIC ANALYSIS}

I have isolated two very different market structures under which for-profit investors may suffer from the presence of nonprofit competition. Each situation requires a different policy analysis. One complaint of unfair competition is easy to dismiss; the other forces us to confront some hard questions of economic justice.

The claims of unfair competition raised by oligopolists should not be taken seriously. American antitrust and regulatory policy makes it clear that there is no public commitment to the maintenance of profits resulting from economic concentration. If successful antitrust litigation forces a cartel to disband, or an oligopolist to divest an acquisition, private investors cannot obtain compensation for their loss of monopoly profits. ${ }^{55}$.Similarly, firms should not be entitled to special protection when the production decisions of nonprofits lower their oligopoly returns.

A harder case arises when investors are deprived of competitive

54. However, in many areas where competition is most brisk, nonprofits cannot be viewed as capital constrained. A fairly common pattern is competition between nonprofits that are "subsidiaries" of large, wealthy tax-exempt organizations such as universities, museums, or churches, and for-profit firms that are small corporations with little or no access to national capital markets. This pattern is common in research and residential care for the retarded or mentally ill.

These cases stand in contrast to nursing homes, hospitals and publishing houses, where for-profits are frequently organized into chains or are part of larger corporations. Organized child day care services with a mix of chains, small independent for-profits and nonprofits, and non-profits affiliated with churches and universities are intermediate cases. See C. COELEN, F. Glantz \& D. Calore, Day Care Genters in The U.S. 3, 83 (1979). Therefore, the forprofit firms that are most likely to complain about "unfair" competition will be those that both face the affiliates of well-endowed institutions and are themselves rationed in the capital market. In fact, this does seem to be the case. The major cases in this area involve travel agents and a testing laboratory. See Kaplan, supra note 2; T. Spiro, supra note 20.

55. The Sherman Act and the Clayton Act both seek to penalize firms which monopolize industries. Instead of compensation, violators may be subject to fines and triple damages awards. See F. ScHERER, supra note 19, at 494-495.

The debate in antitrust policy over controlling market structure versus controlling behavior suggests that an active policy to reduce monopoly profits wherever they occur would be controversial. This debate does not imply, however, a public commitment to preserving monopoly returns. 
returns by the unanticipated entry of nonprofits. It is true that investors in a capitalist economy do not imagine they are guaranteed a competitive return by the government: Tastes may change, competitors may develop new technology, and so forth. But when competitive losses can be traced to particular government actions, the state has a special responsibility to justify its conduct. ${ }^{56}$ Thus, the fifth amendment requires compensation if the government confiscates private property. ${ }^{57}$ Of course, nothing so extreme is in question here. Rather than seizing firm assets, the government is "merely" manipulating the business environment to the advantage of nonprofit firms. Furthermore, it will never be entirely clear how much of the investor's losses are due to the tax-exempt status of some competitors and how much is due to other causes. On the level of constitutional theory, it is not clear what difference the "indirect" character of the government's taking ought to make in assessing the firms' right to compensation. ${ }^{58}$ Whatever the theory, however, the case law plainly suggests that contemporary courts would refuse to extend the fifth amendment to cover tax-related claims of "unfair competition."

Courts, however, are not the only institutions concerned with unfair governmental manipulation of the business environment. As the current tax law indicates, Congress itself has chosen to restrict nonprofits in the name of fairness. But the tax "on "unrelated" business income is exactly the wrong way to respond to the problem. The

56. See B. Agkerman, Private Property and the Constitution 145-50 (1977); L. Tribe, American Constitutional Law 456-65 (1978); Michelman, Properly, Utility and Faimess: Comments on the Ethical Foundations of 'Just Compensation' Law, 80 HARV. L. REV. 1165 (1967).

Graetz, Legal Transitions: The Case of Retroactivily in Income Tax Revision, 126 U. PA. L. REV. 47 (1977), discusses the issue in the context of changes in the income tax law, but he fails to note the relationship between losses caused by tax law changes and unconstitutional takings of property. Instead he assumes "that any tax law changes considered here do not amount to 'takings.' " Id. at $64 \mathrm{n.54}$. He then goes on to present a range of arguments for and against grandfathering. Although "firm conclusions are difficult," he wishes to make the tax law "flexible" and argues that "[p]eople should make investments with the expectation that political policies may change." Id. at 87 . On the similarities between taxation and takings, see Ackerman, Four Questions for Legal Theory, in NOMOs XXII, PROPERTY 351, 362 (J. Pennock \& J. Chapman eds. 1980).

57. U.S. CONST. amend. V. See also B. ACKerman, supra note 56, at 116-118, 133-35; L. TRIBE, supra note 56, at 459-63; Michelman, supra note 56 .

58. Michelman argues that a utilitarian policymaker would require compensation to be paid only if the public measure "can easily be seen to have practically deprived the claimant of some distinctly perceived, sharply crystallized, investment-backed expectation." Michelman, supra note 56, at 1233. For a broader view of the takings clause, see B. ACKERMAN, supra note 56.

59. See Alco Parking Corp. v. City of Pittsburgh, 417 U.S. 369 (1974) (tax designed to harm competitive position of for-profit firms does not constitute a taking). 
nonprofit sector is, after all, rather small relative to the economy as a whole. $^{60}$ If the sector's productive business investments were spread across the economy, they would be unlikely to have much competitive impact. ${ }^{61}$ But the tax on "unrelated" business income prevents such dispersion. Tax-exempt firms must now concentrate their profitable endeavors in those few lines of business judged to be "related." For example, the growth of gift shops and vacation tours operated or sponsored by nonprofit organizations may be, in part, a response to the conditions of the tax law. ${ }^{62}$ Such concentration in a few areas makes it much more likely that the business activities of nonprofits will impose losses on competitive for-profit firms. Of course, these losses were only unanticipated by firms that were in the industry at the time of the substantial entry of nonprofits. But since the IRS and the courts continue to modify the definition of "unrelated," the statute probably continues to impose new windfall gains and losses on competing for-profit corporations as well as on nonprofits that rely on superseded rulings. ${ }^{63}$

It appears, then, that the tax on unrelated business activity creates more unfairness than it can possibly prevent. It should therefore be repealed. It is less clear what, if anything, should be put in its place. If the IRS is to pinpoint instances of "unfair" competition, it would have to carry out an economic analysis that hinges on difficult issues of market structure. Nonprofits might be given the right to enter any business subject to a finding by the IRS that further entry is likely to depress for-profit returns below competitive levels. Regulations explicating this standard would emphasize three factors-the prevailing rate of return in the industry, the speed and volume of nonprofit entry, and the costs of exit for for-profit firms. As similar inquiries in antitrust and public utility regulation suggest, this will often require the use of a great deal of discretion. ${ }^{64}$ Nevertheless, the

60. See note 35 supra.

61. See Klein, supra note 11, at 63-64 n.212. If a nonprofit should obtain control of a large firm in some industry, it would be likely to do no more than limit monopoly profits in that industry.

62. T. Spiro, supra note 20 , details the legal challenges of for-profit providers in these industries.

63. See Cooper, supra note 3; Greenbaum, supra note 6; Kaplan, supra note 2; Webster, supra note 4. For example, the IRS currently appears to be tightening the definition of "unrelated" at least with respect to universities. See Bromberg, supra note 5.

64. In Smyth v. Ames, 169 U.S. 466 (1898), the Supreme Court held that a public utility is entitled to a fair return on the value of its investment. It refused, however, to indicate precisely the economic meaning of its standard, saying "[h]ow such compensation may be ascertained, and what are the necessary elements in such an inquiry, will always be an embarassing question." Id. at 546. This standard was replaced in the 1940 s by a standard 
principles are clear: First, firms earning supercompetitive profits have no right to protection from "unfair" competition. ${ }^{65}$ It is only when this first principle is satisfied that a second issue should be reached. Here, the IRS would determine whether nonprofits are entering at a rate that could have a substantial impact on for-profit returns. Finally, the IRS would have to be convinced that the exit costs of for-profits will be substantial. Once again, the use of discretion is inevitable-but the existence of very specialized human and physical capital would be the focus of concern.

A successful showing of unfair competition would be rare under these guidelines. Indeed, the process seems so cumbersome, and the gains in fairness so elusive, that a simple repeal of the present tax on unrelated income seems the better alternative. By permitting nonprofits to enter any profitmaking industry, repeal will reduce the pressure on for-profit firms in areas that are "related" to the primary activities of nonprofits. While this new freedom may increase the overall level of nonprofit entrepreneurial activity, ${ }^{66}$ the diffusion of this activity throughout the economy reduces the chance that investors in a particular industry will suffer substantial unanticipated losses from nonprofit entry. ${ }^{67}$

that asked whether "the total effect of the rate order [is] unjust and unreasonable." Federal Power Comm'n v. Hope Natural Gas Co., 320 U.S. 591, 602 (1944). Tribe notes that this is a test which "only the most egregiously confiscatory rate structure would have difficulty meeting." L. TRIBE, supra note 56, at $461 \mathrm{n} .3$ (1978).

65. This is the implication of the antitrust laws and of rate of return regulation for public utilities. See F. Scherer, supra note 19, at 475-94; note 55 supra.

66. The increase will be larger if nonprofits are permitted to borrow to finance these investments. Currently, nonprofits can invest in real estate without paying taxes on their earnings, but they are not permitted to borrow to finance these investments. See Bittker \& Rahdert, supra note 3, at 322-25. If, in fact, tax-exempt firms took advantage of their favorable tax position to engage in arbitrage so that a major share of the economy's investment funds passed through their organizations, then the hands-off policy recommended in the text would have to be re-examined. However, since lenders do not lend at favorable rates to highly leveraged firms, such arbitrage is unlikely given the limited resources available to taxexempt firms from private donations.

67. Current changes in the depreciation allowances permitted for tax purposes, see Economic Recovery Tax Act of 1981, § 201, I.R.C. \$168 (West Supp. 1982), will reduce the taxes of most corporations. This tax reduction will work against any expansion of nonprofit investments in competitive markets by reducing the tax advantages of debt. It is no longer so likely that nonprofits will find that productive investments will dominate the purchase of bonds for purely tax reasons. 
HeinOnline -- 34 Stan. L. Rev. 1040 1981-1982 